\title{
Teachers' Critical Reflections on the New Normal Philippine Education Issues: Inputs on Curriculum and Instruction Development
}

\author{
Aljon Delmo Galang ${ }^{1^{*}}$ \\ ${ }^{1}$ Philippine Normal University, Philippines \\ *e-mail: galang.ad.@pnu.edu.ph
}

\begin{abstract}
Due to the COVID-19 pandemic, the Philippine educational landscape is greatly affected. This education issue concerns the country's curriculum and instruction (CIN), covering students' learning, delivery modalities, competencies, teachers' characteristics, and community involvement. Nonetheless, the CIN must be developed, considering the students, teachers, community, and the pressing challenges in the teaching-learning process, promoting quality education while considering the pandemic, by looking into teachers' perspectives. This qualitative research used content analysis to derive insights from the critical reflections of sixteen (16) teacher participants. It aims to present the participants' reflections on the New Normal education issues, leading to curriculum and instruction development inputs. Furthermore, the emerging themes are (a) essentiality and feasibility in choosing learning competencies; (b) good quality, flexibility, sustainability, and safety in choosing learning modalities; (c) learning materials' alignment, sufficiency, and proper distribution; (d) devotion, adaptability, and helpfulness of teachers; (e) reaching out students and task individualization; and (f) leadership and involvement needed to achieve success in education. Moreover, the findings suggest that the New Normal classroom requires a curriculum and instruction, teacher, leadership, and involvement adaptive and flexible of the changing and multifaceted educational landscape brought by the persisting disease.
\end{abstract}

Keywords:

Critical Reflections; Curriculum and Instruction; New Normal; Teaching and Learning Process

\begin{abstract}
ABSTRAK
Karena pandemi COVID-19, bidang pendidikan Filipina sangat terpengaruh. Masalah pendidikan ini menyangkut kurikulum dan pengajaran (CIN) negara yang mencakup pembelajaran siswa, modalitas penyampaian, kompetensi, karakteristik guru, dan keterlibatan masyarakat. Meskipun demikian, CIN harus dikembangkan, mengingat siswa, guru,
\end{abstract}


masyarakat, dan tantangan yang mendesak dalam proses belajar-mengajar, mempromosikan pendidikan berkualitas sambil mempertimbangkan pandemi, dengan melihat perspektif guru. Penelitian kualitatif ini menggunakan analisis isi untuk memperoleh wawasan dari refleksi kritis dari enam belas (16) peserta guru. Hal ini bertujuan untuk menyajikan refleksi peserta tentang masalah pendidikan New Normal, yang mengarah pada masukan untuk pengembangan kurikulum dan instruksi. Selanjutnya, tema yang muncul adalah (a) esensialitas dan kelayakan dalam memilih kompetensi pembelajaran; (b) kualitas, fleksibilitas, keberlanjutan, dan keamanan yang baik dalam memilih modalitas pembelajaran; (c) keterpaduan, kecukupan, dan distribusi bahan ajar; (d) pengabdian, kemampuan beradaptasi, dan bantuan guru; (e) menjangkau siswa dan individualisasi tugas; dan (f) kepemimpinan dan keterlibatan diperlukan untuk mencapai keberhasilan dalam pendidikan. Selain itu, temuan menunjukkan bahwa kelas New Normal memerlukan jenis kurikulum dan pengajaran, guru, kepemimpinan, dan keterlibatan adaptif dan fleksibel dari lanskap pendidikan yang berubah dan beragam yang dibawa oleh penyakit yang terus berlanjut.

\section{Kata Kunci:}

Refleksi Kritis; Kurikulum dan Instruksi; Normal Baru; Proses Belajar Mengajar

\section{Introduction}

The curriculum, along with instruction, is undeniably reshaped by the circumstance within the society. This is the educative tool that adapts to the national landscape of a country. As Villena, Reyes and Dizon (2015) emphasized, the curriculum must address the needs of society, for it should not only mold what ideals the citizens have but also what emerging social clamor exists and what rising condition persists. This is true in this time of the pandemic. There are numerous adjustments made and to be made due to the effects and persistence of COVID-19. In the Philippine academe, teachers and student's involvement in the instruction have been continuously affected due to the protocols made by the Inter-Agency Task Force (IATF) to prevent the widespread of the virus and its variants as it permeates primarily through human movement (Philippine Department of Health, 2021; Ancho, 2020). As a result, teachers must deliver the instruction to the learners in the safest way possible.

The Philippines' Department of Education (DepEd) has been engineering the best learning modality mechanisms to surpass the challenges of the pandemic to the Filipino academe (Philippine Department of Education, 2020). However, it all begins with the curriculum. Since it is the backbone of the teaching-learning process, it is the primary priority to mold into the circumstance in which the classroom setup is in. If the curriculum is set, the possible learning modalities and the prospective learning materials for instruction follow. In other words, it brings forth the revision of 'recommended' and 'supported' curricula. 
On the one hand, the recommended curriculum pertains to the curriculum made and suggested by scholars and professional organizations; on the other hand, the supported curriculum is the set of materials to be used in the delivery of instruction (Villena, Reyes, \& Dizon, 2015; Ornstein \& Hunkins, 2018). The curricula mentioned above are the two major concerns of the study. Moreover, the instruction links the 'potential' and 'actual' results of the curriculum. It is the vital bridge connecting the curriculum aspirations and the 'learned' curriculum (LdC); therefore, it also shows 'how' to deliver the curriculum target content to the learners. Furthermore, the LdC is the bottomline curriculum and what students learn.

Nonetheless, before achieving such, one must lay out valid and reliable instruction. A valid and reliable instruction hits what it is meant to target and hits it in all learning circumstances and milieu. Hence, the instruction must be chiseled and stretched out to execute, if not quality, at least a minimum of what is expected of the learners in consideration of the present-day pandemic.

However, the Philippine Enhanced K to 12 programs and the instruction were designed long before the pandemic began without projecting that this public health concern may happen. Hence, this results in a curriculum and instruction (CIN) dilemma when the COVID19 has begun to strike in March 2020 in the country (World Health Organization, 2020). The Philippine CIN is not prepared for such a situation. Still, the perplexity must be and thus, is continuously addressed. This is to beat the demands of quality education, the foundation of a strong nation, even in the adversity brought by the disease. Philippine education faces turmoil, but it must not stop. In other words, there is no other way but to re-mold the CIN to make a perfect fit for the New Normal.

In re-inventing the facets of the recommended curriculum, the advent lies in the learning competencies (LCs). LCs are the specific target skills within a course. These are the individual nuclei and foci of the curriculum and instruction. These are the competencies to gain cognitive, affective, and psychomotor development in the subject matter. As mentioned, the curriculum provision happened in the pre-COVID19 Philippine educational setup; therefore, the LCs must be adjusted. This is when the Essentialist point of view takes place. The pressing query is: "What are the most essential among the learning competencies?" This leads to ripping the LCs from approximately 14, 171 to 5,689, or a reduction of 60\% (Malipot, 2020). Thus, this also results in the decongestion of the curriculum, promoting academic ease both for teachers and students.

Another pressing priority is the learning delivery modalities (LDMs) which concerns the instruction. The Philippine Department of Education provides the possible learning delivery modalities that may fit into the needs and situations of the students at present. The distance learning delivery modalities include modular distance learning (MDL), blended learning (BL), and Homeschooling (Codamon, 2020). MDL is for those students without internet connections. It may be in the form of printed or digital modules. BL combines online distance learning, both synchronous and asynchronous, MDL, radio, and television-based instruction. The last one is homeschooling. Students learn with their parents, guardians, and/or tutors as authorized learning facilitators instead of teachers in this modality. However, this is still under the review of the DepEd 
Central Office. Though there are options to choose from, not all teachers and learners are adept with these LDMs; thus, this is still subjected to further instructional evaluation and development.

One vital concern is the supported curriculum. This time, the consideration is the set of learning materials (LMs) to distribute. The LMs must be and are constructed based on the multiple aspects of the learners such as their level of academic proficiency and/or stage of cognitive development, community's health condition, availability of information and communication technologies (ICT) and/or printing resources, and of course, the learning delivery modalities appropriate for their context. Online synchronous and asynchronous learning modalities are ideal types of distance learning since classes can still be held virtually as usual, aside from the sociophysical contact avoided during this time (Almario \& Austria, 2020). However, not all students, even teachers, have a strong internet connection in the country. Nonetheless, in most cases, the primary LM is module since, among the distance learning types, modular learning is the safest and most convenient, not only preventing frequent contacts which heightens the possible transmission of the virus, but also it can cater to the educational needs of the learners in the absence of internet connection. Though this is the safest and most convenient, the challenges of clerical tasks of writing and printing modules for teachers, self-learning for students, and learning guidance for parents are yet to be overcome.

Studies related to the execution of education in different countries were conducted to capture the current education situations in their countries as the COVID-19 persists. Relevant policies are indeed checked to see how they affect the educational landscape within their borders. In Indonesia, a study was conducted to see how Large-Scale Public Restriction or Pembatasan Sosial Berskala Besar (PSBB) affected the formal education done online. This study aimed to check the current situation of the country's education upon the implementation of the policy (Siswati, Astiena, \& Savitri, 2020). In the United States, another investigation was made on how the pandemic disrupted early childhood education in their country. This also focused on how such disease even shaped the policies related to education (Barnett, Grafwallner, \& Weisenfeld, 2021).

Moreover, the comparison of the Old and New Normal trends in education delivery is also a topic of discussion. In fact, in Thailand, another related study was done to compare and contrast the advantages of the traditional and online classes and explore the possibility of having the latter as an effective alternative to the former (Charnbhumidol, Kraiwanich, \& Kraiwanit, 2020). In Turkey, a researcher-made a study on the experiences of teachers in online education. The study shows that most Turkish teachers preferred face-to-face classes rather than online learning (Inan, 2021). In Vietnam, the effects of the pandemic on higher education institutions have been highlighted in a study. The investigation focused on e-learning and related technology-based education deliveries (Pham \& Ho, 2020).

There are various studies made in other countries related to the effects of the pandemic on their educational system. However, the foci of these studies are primarily on the delivery of the instruction, relevant policies, and the effects of the pandemic on the academe. Nevertheless, this 
study at hand does not solely focus on the facets above of education. This investigation aims to go over the different elements of curriculum and instruction such as learning competencies, delivery modalities, materials, instructional tasks, teachers' attitudes, leadership, and community involvement. The reason behind this is that this study sees the improvement of curriculum and instruction as a way to address the pressing clamors and education demands of today's learners.

It is indeed apparent that the primary concern of today's education is the recommended curriculum, precisely the learning competencies, the instruction through learning delivery modalities, and the supported curriculum, particularly the learning materials. However, though these are the afflictions of the time, it is still possible to address the following issues, and this can be done through the help of the front-liners of the edification team - the teachers. With the help of critical reflections, inputs to address the issues above may be addressed. This study aims to present the critical reflections of the teachers on the issues of the New Normal education, leading to inputs for curriculum and instruction development. Thus, it targets to answer the questions: (a) What are today's curriculum and instruction concerns? (b) What are the inputs derived from the critical reflections used as inputs for curriculum and instruction development?

\section{Methods}

This study used the qualitative research method due to the nature of its non-numerical data. This method relies on text and image data, has unique steps in data analysis (coding and thematic analysis), and draws on various designs (Creswell, 2014). Specifically, the investigation used content analysis of the teacher's critical reflections on the new everyday education issues. Content analysis is an organized way of coding and idea taxonomizing that allows further exploration of textual information to identify the patterns of words and/or sentences used, their frequency, relationships, and communication structure and discourses (Grbich, 2007).

Furthermore, as Brookfield (2009, cited in Galang, 2020), critical reflections are made to contend and unveil the existing ideology or concept and can be used to bring about change. In this study, critical reflections as outputs were made from the learning action cell on curriculum and instruction issues, conducted among sixteen (16) senior high school teachers.

The teacher participants were individually asked to develop such written reflections on the current education issues related to curriculum and instruction, considering the constraints brought by the current public health crisis. The questions asked were: "(a) What are the main concerns of today's education related to curriculum and instruction?" (b) "What help do you need to address such issues?" The reflections were then collected right after the accomplishment of the task. Eventually, in analyzing the data gathered, the participants' perceived and observed issues were identified through coding. The surfacing codes were taxonomized, and in due course, they were arranged and presented into themes. From these emerging themes, inputs to curriculum and instruction development were derived. 


\section{Results and Discussion}

It has always been evident that curriculum and instruction's primary concern and springboard are the need for society and its current condition. Hilda Taba's Grassroots Model of curriculum development emphasizes the importance of needs diagnosis. This is the first step in formulating educational experiences for learners in such a model (Ornstein \& Hunkins, 2018). The needs of the learners are identified and incorporated in developing the curriculum. This approach appears to be clinical. As the doctor diagnoses the patients' diseases to come up with a prescription, the curriculum expert surveys the needs of the learners to produce better learning achievements, addressing the opportunities and threats of the time. Today, in this unexpected 360-degree shift in the educational landscape, these needs are doubled. Nonetheless, the question is which phase in the curriculum development process the education experts should begin with.

It must be noted that in a linear sequence, curriculum designing and planning come before implementation, and in today's Philippine setting, the existing curriculum has already been designed and planned long before the pandemic; hence, the probable impact of the disease on education is not included in the initial processes. Formulating a new curriculum that will embrace the unpredictability of the epoch's education nature, just to address the rough shift in the classroom setup is strenuous and next to impossible. Hence, fixing the current situation cannot be done by formulating a new curriculum but through curricular amendments that can be done in the curriculum implementation. In other words, the diagnosis of today's needs is not for designing and planning a new curriculum but for curricular amendments in its implementation, addressing the needs of the time leading to its development.

Change is inevitable, especially in this unpredictable epoch of persistent disease. Since the challenge of the curriculum is to address the needs of the society, it is pretty challenging to pursue its endeavor of social progress through its development and fix the schooling situation of this generation's learners. However, the only way is to adjust is to change. John McNeil (n.d., as cited in Ornstein \& Hunkins, 2018) listed complex types of change in curriculum implementation and three (3) of which are substitution, alteration, and perturbations. In implementing the curriculum, teachers may use an instruction element instead of the existing suggested one (substitution). There are also instances in which one presents new and better learning modalities and materials that can easily be adapted (alteration).

Furthermore, there are also times when changes may roughly hamper the delivery of learning but can eventually be adjusted within a short period (perturbations). In other words, these types of changes may be done in the curriculum implementation phase and through instruction itself (Sahlberg, n.d.;). However, to push through with these changes, the diagnosis of today's needs by identifying this time's education issues is required. Nonetheless, this study surveys such issues by analyzing the critical reflections made by the teacher participants to provide inputs for curriculum development. 
Upon analyzing the content of the critical reflections of the teacher participants, there are six (6) emerging themes identified. They are (a) essentiality and feasibility in choosing learning competencies within the curriculum; (b) good quality, flexibility, sustainability, and safety in choosing the best learning delivery modalities; (c) alignment, sufficiency, and proper distribution in honing and sharing learning materials; (d) devotion, adaptability, and helpfulness in describing the teachers needed in the new normal classroom; (e) reaching out students and task individualization in executing the task for the learners; and (f) leadership and involvement in helping one another to achieve success in education.

\subsection{Essentiality and Feasibility: Choosing Learning Competencies within the Curriculum}

The teacher participants realize that it is essential to choose the essential learning competencies and set aside the skills that cannot be achieved through instruction due to time constraints. Though all the skills are essential, the essential ones must be chosen to consider their usefulness and possible delivery (Department of Education, 2020). Hence the keyword is 'most essential.

This is emphasized in the critical reflection of a participant. Participant 7 said:

"Hence, the main concern of the curriculum standards must be the level of learning competencies' essentiality and their safest delivery modes. For example, in teaching

21 Century Literature, the teacher must consider the literary analysis writing skill instead of focusing on the familiarization of representative authors and texts. This is also important, but the writing skill is more important (Excerpt 1)."

Furthermore, one of the participants also mentioned that the academe must ensure that learning, by all means, must continue, and this can also only happen when it is considered in curriculum development. It was also emphasized that the decongestion of the learning competencies could be of great help to ensure learning continuity. This is true because focusing on the essential ones would trim down the learning competencies. Fewer competencies mean a high possibility of continuous delivery. Participant 8 affirms that "the fundamental concerns in terms of curriculum standards that need to be addressed to ensure learning continuity. To cite an example is the decongestion of lessons and/or learning competencies in the curriculum" (Excerpt 2).

Curriculum endurance (CE) is also emphasized by one of the participants. As shown in Excerpt 3 below, the strength of the curriculum to stand the pandemic test is vital to the survival of the educational system. The curriculum's ability to cater to the needs and consider the level of adaptability of the learners is essential to maintain CE.

Aside from the needs of the students, the way the learners adapt to the current situation must be of significant consideration. A learning competency may be essential but becomes useless when it is impossible to deliver such. In other words, choosing which learning competency is the most essential goes along with identifying which will be feasible. Essentiality must jive with feasibility. 
This is indeed what one of the participants pointed out. Participant 11 highlighted in her critical reflection that:

"As a teacher, the fundamental concerns in terms of curriculum standards are the curriculum's endurance despite the global pandemic and its challenges to the education sector and another is its essence to the learners in terms of their needs and adaptability level especially this new normal set up (Excerpt 3)."

Today's curriculum development must be essentialist. In other words, this educational backbone must be a curriculum of survival. Embellishment learning competencies that are intentionally and unintentionally made to make the curriculum academically hifalutin and pretentious must be omitted. They merely congest both curriculum and instruction and bombard both teachers and learners with tasks that are not useful in their dealings with other people and solely lead to trivial knowledge. Moreover, as mentioned, it is not enough to identify what is essential. It also goes with the sortation of what is feasible. LCs may be essential, but they cannot be executed due to the pandemic's constraints. Hence, it is not wise to force the teaching force to execute those in the instruction. This can only lead to teachers' and learners' frustration due to such a delusive target that cannot be accomplished in reality. However, aside from the essentiality and feasibility of executing the learning competencies, another concern is how to deliver these through instruction. Once the essential and feasible are sorted, the next step is implementing them in the edification process. That is why learning delivery modality is a factor to consider. This is discussed in the next section.

\subsection{Good Quality, Flexibility, Sustainability, and Safety: Choosing the Best Learning Delivery Modalities}

Another concern is the learning delivery modalities (LDM). As mentioned, it is vital in executing the instruction. It is the tool that makes the educative process possible. However, in the present-day conflict, teachers and students find it challenging to meet and involve in the edification process. Nonetheless, the Department of Education can give both teachers and students (Codamon, 2020). Participant 5 stated in her critical reflection that "the fundamental concerns in terms of curriculum standards are ... execution of multiple learning delivery modalities" (Excerpt 4).

Nevertheless, aside from various options, the teacher participants added that LDM must be good quality, flexible, and sustainable. This is true since it is not enough that the delivery of quality education is good quality. It must go with flexibility and sustainability. It must be flexible to cater to the different situations of the learners and must be sustainable to be done until needed.

Participant 1 also agreed on this matter. The teacher said:

"Covid 19 like a ghost for me. In one snap, all our normal life change a lot. As an educator, I must find sustainable, quality, flexible learning options to help my students in the teaching-learning process. I will apply the modalities such as distance learning, modular learning, and homeschooling (Participant 1, Excerpt 5)." 
In addition, one of the participants also asserted that the LDM must be delivered in the safest way possible. This is always the primary concern not only of the academe but of the whole country. The protocols must always be followed to provide safety precautions for both teachers and students to prevent them from getting inflicted with the fatal virus. It is always that the safety of the stakeholders is the top priority of the whole academe and community. As perceived, Participant 7 stressed out that "the main concern of the curriculum standards must be ... their [learning competencies'] safest delivery modes" (Excerpt 6).

Indeed, LDMs play as indispensable vehicles of instruction that make the teaching-learning process move forward, even in the face of the pandemic. The modalities that must be chosen are supposed to be versatile that they can be used in the different situations of each learner. They must become an enormous way to cater to the needs of the students, not a tremendous hindrance in the delivery of instruction, due to their exclusiveness brought by the limits of learners' instruction accessibility. They must also be sustainable that both teachers and learners can subscribe to such until the end of the program. Furthermore, since a pandemic exists, safety is the primary concern of the instruction as education is impossible without the teachers and the learners themselves. Hence, a safe delivery leads to fruitful instruction, entailing better learning outcomes. Apart from choosing the appropriate LDM, the primary concern of CIN in the New Normal is selecting the appropriate learning materials - the supported curriculum. This is also an essential element to succeed in the teaching-learning process. This is extrapolated in the next section.

\subsection{Alignment, Sufficiency, and Proper Distribution: Honing and Sharing Learning Materials}

The supported curriculum plays a significant part in the success of the learning process (Villena, Reyes, \& Dizon 2015; Orstein \& Hunkins, 2018). The preparation of the proper learning materials and the curriculum amendments needed, and the learning delivery modalities make a tool that can make the aspirations of the prescribed curriculum transpire among the students. Furthermore, the learning materials (LMs) must be aligned with the current situation that we are in. It must be accomplished by the learners in the absence of the teachers. Though parents and guardians are also there to guide them, the LMs must aid in learning, not an instrument of torture. Participant 5 agreed that "the fundamental concerns in terms of curriculum standards are the learning continuity through K-12 curriculum adjustments, alignment of learning materials, and execution of multiple learning delivery modalities" (Excerpt 7).

It is unquestionable that aside from the quality of the LMs, their quantity is another thing to deal with. Many students are still enrolled since they do not want to stop studying since they want to finish Basic Education on time. Due to this reason, the academe, as lead by the Department of Education, must provide sufficient materials for printing, especially the modules, especially for those who do not have an internet connection and rely solely on printed LMs. As Participant 12 pointed out, the availability of the LMs cannot be neglected. He said that "the fundamental concerns in terms of curriculum standards that need to be addressed to ensure learning continuity is the availability of modular supplies to be distributed in each division and school itself' (Excerpt 8). 
Once the LMs are ready, the next challenge is to distribute them. The distribution and retrieval of the learning materials must also be planned well since it is another task. The proper procedure for disseminating the materials is needed so that the learners will be able to receive them most safely without getting the virus. In addition, the IAFT (Inter-Agency Task Force) protocols must be considered to make this possible. This is the concern of Participant 10. The participant said, "However, my concern is the physical delivery of the learning materials; we all know it is a health risk. I believe that it should be addressed properly and seek help from different stakeholders" (Excerpt 9).

As emphasized and analyzed, learning materials must align with the pandemic-driven changes in CIN and LDMs. These materials must deliver the aspirations of education targets adapting to the current public health crisis. They must also be sufficient as their supply determines the possibility of instruction delivery. Their insufficiency can result in instruction failure. In addition, they must also be appropriately distributed. Even though there are many means to make the materials accessible to learners, a safe way of destruction must be the number one priority. Furthermore, aside from preparing the materials, the role players of instruction, the teachers, must be also be prepared for the significant shift in the educational platforms since they are the facilitators of the teaching and learning process.

\subsection{Devotion, Adaptability, and Helpfulness: Describing the Teachers Needed in the New Normal Classroom}

The process of executing the instruction already pushes through in the Philippine archipelago (Nicholls, 2020). However, its end is still uncertain. Its success is still unknown since the present situation is unusual. Nobody can foresee the future of Philippine education in this kind of constraint, but the teachers as front liners of curriculum and instruction must be prepared and adaptive to the situation. As Participant 2 claimed, though the success of remote learning is unseen, devotion to the delivery of instruction for the learners must be done. She said, "Uncertainty is very high as to whether remote learning will be successful at this time or not. That is why as a teacher, I would devote myself fully to deliver the quality learnings that students should receive" (Excerpt $10)$.

Aside from total devotion to students' learning, one of the participants also pointed out that teachers must be adaptive and open to the changes and challenges of the New Normal instruction. Teachers who already fixed themselves in the traditional old normal have no place in today's academe. Teachers who are willing to learn new things are the ones who are fit to execute the instruction in these trying times. This is the prescription of participants, as shown in their responses below. Participant 4 stated, "As a teacher, we need to be flexible enough and willing to accept new changes to cope up with the new normal teaching pedagogies" (Excerpt 11). Furthermore, Participant 14 stated, "Being adaptive to the changes that arise during this time is necessary to get along with the new education setting we are currently in" (Excerpt 12). 
Participant 16 added, "We, teachers, really need to give our helping hands for those students who cannot adapt to this new normal" (Excerpt 13). As he said, today's teachers must help the students adapt to the current situation that this generation is in. The teachers with parents and guardians must extend their helping hands, especially to the Youth who find it difficult to live and study in the New Normal. Furthermore, another major concern is how teachers should execute the tasks for learners in this kind of situation. This must also be done appropriately.

\subsection{Reaching out Students and Task Individualization: Executing Task for the Learners}

A primary concern of students learning is reaching the students out, especially those far from the school's location. The school must find a way to deliver the learning materials to their places. It is when they are reached out and provided with their learning needs that education begins. This is a fact, as Participant 2 agreed. She said, "One concern is how the learners will be reached if their location is situated in the remotest areas" (Excerpt 14).

The instructional tasks must be primarily individualized as much as possible (Garcia \& Weiss, 2020). Immersion and interaction with the community must be avoided to keep the learners safe from the threats of the virus. The teachers must be kind enough to make materials that can make the students learn even when they are alone. Activities that apply to the face-to-face situation must be changed and crafted to fit the students' context. This is what Participants 11 and 13 affirmed. Participant 11 said, "Performance tasks which require students and community interaction will no longer be included (Excerpt 15)."

As highlighted in her critical reflection, Participant 13 said:
"In addition, greater focus will be given to individualized learning rather than collaborative learning. The $K-12$ curriculum is performance and competency-based, and since face-to-face learning cannot happen this time, certain modifications in the curriculum should be considered since there are performances that can only be done in face-to-face learning (Excerpt 16)."

Reaching out to the learners is indeed an arduous task for the teachers themselves as they need to consider the different facets of student learning, such as students' individuality in learning and their current health condition and restriction. This task may appear to be an enormous burden to teachers, but it is one of the indispensable ways to make the delivery of instruction possible.

Evidently, in the discussions in the previous sections, today's ideals and realities of teaching and learning have been discussed. Nonetheless, all of the ideals of the teacher participants are impossible if they will do it alone. They need help, especially from the school heads, the experts, and most especially the Department. The help that they shall extend will significantly affect the execution and success of education delivery in this time of the pandemic. 


\subsection{Leadership and Involvement: Helping One Another to Achieve Success in Education}

The task of edifying the Youth is not a one-person task. This must involve all the stakeholders to make this endeavor successful even within the constraints of the pandemic. This is the task of the whole community. One must think that he or she is involved in the challenge that we face today. When everybody helps one another, all the educational targets of the nation can be attained. This is what Participant 1 agreed on. She said, "I do not think that teachers can solve this alone Because I believe in a saying that more heads are better than one" (Excerpt 17).

At the school level, the school heads must be proactively involved in delivering the instruction (Australian Institute for Teaching and School Leadership Limited, 2020). They must be the living compass that leads, especially the teaching force to maintain the curriculum and instruction standards. Their supervision and observation inputs help develop contextualized plans and needed amendments to attain victory in all facets of the pedagogical tasks. This is reinforced and claimed by Participant 3. The teacher stated, "This concern could not be solved by teachers alone because there must be a collaborative effort from the higher-ups, like the ones that are experts in curriculum development and consultation with the administrators and community linkages as well" (Excerpt 18).

At the community level, the parents and guardians and the whole community are inevitably involved in this task. Participant 3 in Excerpt 18 and Participant 4 in Excerpt 19 that they also have roles to play in educating the Youth, even in the Pre-CoViD19 classroom and most especially today. Participant 4 mentioned that "the different learning modalities are the ways for learning continuity, but it could not be solved by the teachers alone, it should also be addressed to the parents, administrators, and community as well for them to work hand in hand to achieve effective learnings" (Excerpt 19).

At the division and national level, the supervisors and the DepEd officials, being the policymakers, are involved. Whatever policy they make and training programs they spearhead can help the teachers and students a lot to cope up with the afflictions of the epoch. As suggested by Participant 6, the webinars on teaching and learning that they shall provide will be of great help to train the teachers to be versatile in executing the instruction, contributing a lot to realizing the curriculum targets. She affirmed, "Teachers must have a clear knowledge and understanding of the different strategies and modalities, which can be learned in training provided by DepEd and the webinar conducted by the supervisor and school Heads" (Excerpt 20).

Furthermore, it must be highlighted that education only materializes when there is teamwork among its stakeholders. The school heads are responsible for leading the teachers to achieve the goals of education and overcome the time's challenges. Their guidance provides a solid foundation in making the instruction take-off. Furthermore, parents and/or guardians must double their active involvement in their children's learning. In the absence of the teachers in real-time instruction, they become substitutes in extending the education at the doorsteps of their homes. Moreover, the 
policymakers on top of the educational hierarchy must also use their authority and expertise to gauge the real needs and picture out the grotesque of today's educational landscape to cascade down policies that will address the needs of both teachers and, most especially, the learners.

Clearly, curriculum experts must focus on the amendments related to education issues in learning competencies, delivery modalities, learning materials, teachers' attitude, reaching students and task individualization, leadership, and involvement to defeat the pandemic's perplexities.

\section{Conclusions}

Through this investigation, the major concern of today's curriculum and instruction development are identified, and they zero in on choosing learning competencies within the curriculum, choosing the best learning delivery modalities, honing and sharing learning materials, describing the teachers needed in the new normal classroom, executing the task for the learners; and helping one another to achieve success in education.

As shown in the discussion, essential and feasible learning competencies within the curriculum; good quality, flexible, sustainable, and safe learning delivery modalities; aligned, sufficient, and properly distributed learning materials; devoted, adaptable, and helpful teachers needed in the new normal classroom; reaching out students and task individualized task for the learners, and leadership and involvement are needed to adapt and be successful in the New Normal classrooms. These are the inputs that the stakeholders, the experts, and the stakeholders must consider to make the New Normal curriculum and instruction development possible.

\section{References}

Almario, AR, \& Austria, Reagan. (2020). Helping K-12 transition to post-COVID 19 times. https://authdocs.deped.gov.ph/wp- content/uploads/2020/06/BE-LCP-Annex-E-Ani-AlmarioHelping-K-12-Schools-Transition-to-Post-COVID.pdf

Ancho, I. V. (2020). Old mindset, values and ethics, and stakeholder partnership and accountability: Inputs to school leadership in the new normal. Jayapagus Press Books. Retrieved from http://jayapanguspress.penerbit.org/index.php/JPB/article/download/463/458

Australian Institute for Teaching and School Leadership Limited. (2020). The role of school leadership in challenging times. Retrieved from https://www.aitsl.edu.au/research/spotlight/the-role-of-school-leadership-in-challenging-times

Barnett, W. S., Grafwallner, R. \& Weisenfeld, G. (2021). Corona pandemic in the United States shapes new normal for young children and their families, European Early Childhood Education Research Journal, 29:1, 109-124, DOI: 10.1080/1350293X.2021.1872670.

Charnbhumidol, P., Kraiwanich, S., \& Kraiwanit, T. (2020). Learning method for the new normal in Thailand. International e-Conference on Impact of New Normal and COVID-19 on Education, Economic, Business Strategies, and Management of the Supply Channel. Retrieved from https://www.researchgate.net/profile/Tanpat-Kraiwanit 2/publication/349117295_New_Normal_and_Covid19_Impact_on_Education_Economic_Business_Strategies_and_Management_of_the_Supply 
Codamon, D. Republic of the Philippines. Philippine Information Agency. (2020). Understanding the distance learning delivery modalities. Philippine Information Agency Official Website.

Creswell, J. (2014). Research design: qualitative, quantitative, and mixed methods. California, USA: SAGE Publications, Inc.

Galang, A. (2020). Non-academic constructs of the 21st century Thai and Filipino teachers in the movie "Teacher's Diary". OKARA Journal, 2 (2), 190 - 208.

Garcia, E. \& Weiss, E. (2020). COVID-19 and student performance, equity, and US education policy. Economic Policy Institute. Retrieved from https://www.epi.org/publication/theconsequences-of-the-covid-19-pandemic-for-education-performance-and-equity-in-the-unitedstates-what-can-we-learn-from-pre-pandemic-research-to-inform-relief-recovery-andrebuilding/

Grbich, C. (2007). Qualitative data analysis: An introduction. California, USA: SAGE Publications, Inc.

Inan, H. Z. (2021). Challenges of Distance/Online and Face-to-Face Education in the New Normal: Experiences of Reggio Emilia-Inspired Early Childhood Educators in Turkey. Pedagogical Research, 6(1), em0086. DOI: https://doi.org/10.29333/pr/9304

Malipot, M. (2020). DepEd to roll out revised K to 12 curriculum amid COVID-19 crisis; reduces required learning competencies by $60 \%$. Manila Bulletin. Retrieved from https://mb.com.ph/2020/05/19/deped-to-roll-out-revised-k-to-12-curriculum-amid-covid-19crisis-reduces-required-learning-competencies-by-60/.

Nicholls, AC. (2020). Education in time of a pandemic: What students and teachers are in for this coming school year. CNN Philippines. Retrieved from https://www.cnn.ph/news/2020/6/11/COVID-19-2020-school-classes.html

Orstein, A. \& Hunkins, F. (2018). Curriculum foundations, principles, and issues. London, UK: Pearson Education Limited.

Pham, H.-H., \& Ho, T.-T.-H. (2020). Toward a "new normal" with e-learning in Vietnamese higher education during the post COVID-19 pandemic. Higher Education Research \& Development, 1-5. DOI: 10.1080/07294360.2020.1823945

Republic of the Philippines. Department of Education. (2020). DepEd order no. 012. Department of Education Official Website. Retrieved from https://www.deped.gov.ph/wpcontent/uploads/2020/06/DO_s2020_012-1.pdf

Republic of the Philippines. Department of Education. (2020). Guidelines on the use of the most essential learning competencies. Department of Education Commons. Retrieved from https://commons.deped.gov.ph/MELCS-Guidelines.pdf

Republic of the Philippines. Department of Health. (2021). Resolution no. 94. Department of Health Official Website. Retrieved from https://doh.gov.ph/sites/default/files/healthupdate/IATFResolution94.pdf

Sahlberg, P. (n.d.). Curriculum change as learning: In search of better implementation. Academia. Retrieved from https://www.sac.smm.lt/bmt/wp-content/uploads/2009/09/1-Passi-SahlbergCurriculum-change-as-learning.pdf.

Siswati, S., Astiena, A.K., \& Savitri, Y. (2020). Evaluation of online-based student learning: Models during New Normal pandemic covid-19 in Indonesia. Journal of Nonformal Education, 6 (2): 148-155. Retrieved from DOI: https://doi.org/10.15294/jne.v6i2.25599

Villena, D., Reyes, E. \& Dizon, E. (2015). Curriculum development. Manila, Philippines: Adriana Printing Co. Inc.

World Health Organization. (2020). Coronavirus disease (COVID-19) in the Philippines. Retrieved from https://www.who.int/philippines/emergencies/covid-19- in-the-Philippines. 